farmers in the case studies and a majority of the San Joaquin farmers paced the work and staggered planting to spread work over a longer season.

Selective mechanization is another technique for leveling out employment over a long period of time. It may mean using less than the most advanced means of labor-saving technology, such as a tomato harvester without electronic sorting, or in some instances continuing to use hand labor. Some farmers decide against fully mechanizing a task after considering the costs and benefits of various alternatives. The money saved by full mechanization may not balance all the costs involved. The Coachella Valley farmer did not mechanize the bean harvest so that he could keep workers employed during the harvest season.

Various new technologies enable farmers to harvest crops earlier and continue production later into the season. Plastic tunnels, hot caps and greenhouse starts are examples. New seed varieties also provide early and late season crops. In some areas farmers can use these technologies to double-crop their land.

Most growers routinely use breakeven or loss crops for agronomic reasons, primarily for disease and pest control. These crops also affect employment patterns. By growing sugar snap peas, a break-even crop, the Coachella Valley farmer filled in the last gap in his annual employment pattern and kept his best workers employed continuously for 10 months rather than laying them off and risking losing them to other growers.

Growers who are unable to extend employment on their own farm can link up with other farmers and nonfarm employers who have work available during the off-season. Fifty-five percent of San Joaquin growers would like to share workers or crews with other growers, and $48 \%$ refer workers to other employers.

Advantages of a year-round employment system. Farmers have found many benefits from a yearround or extended employment system. Some of theses are increased worker availability, increased productivity and dependability, less need for

\title{
Coalition promotes sustainable practices
}

\section{Dave Campbell}

Funded in May 1993 by a 3-year, $\$ 2$ million grant from the Kellogg Foundation, the California Alliance for Sustainable Agriculture (CASA) is working to develop more sustainable food and agricultural systems. The coalition is the largest of 18 community-based projects funded in Kellogg's Integrated Farming Systems initiative. The initiative is designed to encourage adoption of more sustainable production methods and create agricultural systems that revitalize rural communities by creating more economic security for small farmers, fair wages for farmworkers and establishing mutually beneficial ties between urban and rural residents.

The grant provides a unique opportunity for UC to collaborate with several innovative non-profit groups in California. Members of the coalition include the UC Sustainable Agriculture Research and Education Program (SAREP), the UC Santa Cruz Agroecology Program, the Bio-integral Resource Center (BIRC), the California Institute for Rural Studies (CIRS), the Community Alliance with Family Farmers (CAFF), the Lodi-Woodbridge Winegrape Commission (LWWC), Pueblo Unido, and the Rural Development Center (RDC).

CASA seeks to build agricultural systems that provide everyone with sufficient healthy food, create just and humane social relations and promote communities suited to the constraints of their natural environments.

During its first year, CASA pursued these goals by creating guides for reducing farm chemical use, introducing integrated pest management practices to wine grape and tomato growers, conducting a sustainable agriculture leadership training program, formulating strategies to enhance local food systems and to use sustainable agriculture as a community economic development tool, conducting a farmworker housing survey, developing a library of Spanish-language materials on sustainable agriculture, and supporting a community planning process in Santa Cruz County for sustaining agriculture in the face of environmental threats and urban development.

In addition, CASA has held roundtable discussions with pest control advisors, Cooperative Extension personnel, and agriculture education teachers. These groups have begun to develop specific action plans to move the state toward sustainability.

CASA members will also work directly with farmers to find better ways of growing crops with fewer chemicals, then marketing them. For example, LWWC is a local commodity commission, which helps its 650 winegrape grower members adopt IPM and seeks markets for their products. CIRS is encouraging organic cotton production by forging an industry-wide coalition that links growers, marketers, environmentalists and pest control advisors.

CASA's steering committee also plans to expand its collaboration to benefit the wide range of California groups interested in sustainable agriculture. For example, it has allocated a portion of its funds to hire a coordinator for a statewide Sustainable Agriculture Working Group (SAWG). Modeled after similar groups around the nation, the SAWG will promote sustainable agriculture policy alternatives and work to link existing groups more effectively.

Representatives of CASA meet regularly with representatives of the other projects to share ideas and strategies.

D. Campbell is Economic and Public Policy Analyst, Sustainable Agriculture Research and Education Program, UC Davis.

For more information on CASA, contact Project Coordinator Kerstin Ohlander at (408) 459-4786. 